Anna Tabisz

ORCID: 0000-0003-1714-7052

Uniwersytet Opolski

DOI 10.19195/1642-5782.17(27).3

\title{
O pytaniach podczas rozmowy maturalnej z języka polskiego
}

W artykule prezentuję wyniki jakościowej i ilościowej analizy pytań zadawanych uczniom przez komisję przedmiotową podczas rozmowy maturalnej. Tekst składa się z trzech zasadniczych części. W pierwszej omawiam kategorię pytania z trzech perspektyw: pragmatycznej, gramatycznej oraz dydaktycznej, w drugiej przedstawiam i komentuję wyniki analizy pytań. Trzecia część artykułu ma charakter podsumowujący.

\section{Pytanie z perspektywy pragmatycznej, gramatycznej i dydaktycznej}

Dla dyskursu edukacyjnego dialog dydaktyczny to typowy gatunek mowy główny sposób komunikowania się nauczyciela z uczniami podczas lekcji. W odróżnieniu od rozmowy potocznej cechuje go między innymi:

— jednostronna asymetria wiedzy, której uzgadnianie przebiega do pewnego poziomu (wynikającego z programu nauczania i scenariusza lekcji);

—zależność przebiegu interakcji od założonych przez nauczyciela celów dydaktyczno-komunikacyjnych;

— zaburzenie reguły spontaniczności — linia tematyczna jest z góry określona (wiadomo, jakie pytania zostaną postawione oraz jakie odpowiedzi powinny się pojawić już w fazie planowania lekcji);

— jednokierunkowość — inicjatorem dialogu jest prawie zawsze nauczyciel;

— specyficzny zestaw aktów mowy (Nocoń 2011: 196), w którym jedno z najwyższych miejsc zajmuje pytanie. 
Z perspektywy pragmatycznej pytania są grupą aktów illokucyjnych określanych głównie pod względem formalnym i intonacyjnym. Wśród badaczy aktów mowy budzą spore kontrowersje. John Lyons pytania opisuje jako pewne podtypy mandów: ,jedną z podklas tak zwanych dyrektyw, czyli wypowiedzi narzucających lub proponujących jakąś czynność lub zachowanie i wskazujących, że powinno ono zostać urzeczywistnione. [...] Nadawca musi [...] sądzić, że adresat jest w stanie zastosować się do dyrektywy" (Lyons 1989: 344-345, za: Kawka 1999: 55). Pytania komunikują ,pragnienie nadawcy uzyskania od odbiorcy informacji na temat tego, co jest zawarte w pytaniu" (Świdziński 1973: 226), zatem podstawowym warunkiem pragmatycznym dla funkcji pytań jest obecność luki informacyjnej, którą nadawca chce uzupełnić (Awdiejew 1987: 132). Pytający spodziewa się od odbiorcy odpowiedzi na swoje pytanie „chce, żeby odbiorca odpowiedział”. Anna Wierzbicka (1983: 129), stosując metodę eksplikacji semantycznej, tak „rozpisuje" ten akt mowy:

Chcę, żebyś sobie wyobraził, że ja nie wiem tego,

co ty wiesz i że ty chcesz mi to powiedzieć

mówię to, bo chcę, żebyś mi to powiedział

By pytanie „zadziałało” - było skuteczne - powinno zdaniem Johna Searle’a spełnić cztery warunki fortunności: 1 . nadawca nie zna odpowiedzi, to znaczy nie wie, czy zdanie jest prawdziwe, lub nie zna informacji potrzebnej do dopełnienia zdania, aby było prawdziwe; 2 . zarówno dla nadawcy, jak i odbiorcy nie jest oczywiste, czy niezapytany odbiorca dostarczyłby w danej chwili informacji; 3. nadawca chce znać informację; 4. nadawca próbuje wydobyć tę informację od odbiorcy (Searle 1987: 88-89). Pierwszy warunek jest konieczny, aby wypowiedzenie uznać za pytanie'.

Przyjmując perspektywę gramatyczną, pytania uznaje się za takie konstrukty językowe, które składają się z dwóch zasadniczych elementów:

części wskazującej, jakie działanie należy wykonać, i części oznaczającej obiekty, na których lub w związku z którymi ma być wykonane działanie. [...] W pytaniach elementami wskazującymi na rodzaje zalecanego do podjęcia działania są zaimki rzeczowne, przysłowne i przymiotne pytajne $^{2}$ oraz partykuła pytajna $c z y$. Biorąc pod uwagę różnice zachodzące w skutkach użycia zaimków pytajnych i partykuły czy, wyróżnia się pytania rozstrzygnięcia i dopełnienia. (Kojs 1994: 34)

W pytaniach rozstrzygnięcia niewiedza nadawcy dotyczy istnienia lub nieistnienia samej sytuacji nazwanej przez składnik propozycjonalny (Skowronek 1999: 58). Pytania te mogą być proste lub rozłączne. Proste „rozstrzygnięcia” dają możliwość odpowiedzi jedynie tak bądź nie, a przedmiotem potwierdzenia lub zaprzeczenia jest sąd w postaci zdania oznajmującego wypowiedziany po partyku-

1 Warto podkreślić, iż pytania stawiane w procesie nauczania uczenia się nie spełniają warunku koniecznego. Mówi się o nich, że są pytaniami pozornymi, dewiacyjnymi czy exam question (Kawka 1999: 58), ponieważ nauczyciel zna na nie odpowiedź.

2 Na przykład jak?, gdzie?, kiedy?, kto?, co?, który?, jaki?, czyj?, dlaczego?, po co?, w jakim celu? 
le $c z y^{3}$ (Kojs 1994: 34). Z kolei na pytanie rozłączne (wieloczłonowe) odpowiada się, powtarzając jeden z członów alternatywy, czyli poprzez wybór lub wykluczenie założenia (Skowronek 1999: 58). Z kolei pytania dopetnienia (inaczej pytania o uzupetnienie) „,dopuszczają” więcej odpowiedzi niż dwie, a ich zakres wyznacza zakres przysłówka czy zaimka pytajnego obecnych w pytaniu, mają strukturę podobną do funkcji zdaniowej ${ }^{4}$ (Kojs 1994: 34).

$\mathrm{Na}$ gruncie dydaktyki istnieje wiele opracowań pytań ${ }^{5}$ uwzględniających rozmaite kryteria. Wojciech Kojs (1994), analizując samą treść pytań, proponuje zestaw dziewiętnastu najbardziej typowych ${ }^{6}$, są to pytania: 1 . egzystencjalne; 2. definicyjne; 3. o genezę; 4. o przynależność; 5. o jakość; 6. o cel działania; 7. o warunki; 8. o sposób działania; 9. o rozwój; 10. o ocenę; 11. o podmiot i przedmiot działania; 12. o skutki; 13. o porównanie; 14. o związki; 15. o przyczynę; 16. o prawdopodobieństwo; 17. o ilość; 18. o budowę oraz 19. o zasady działania (Kojs 1975: 80-82). Jolanta Nocoń (1994), stosując klasyfikację semantyczno-funkcjonalną, wyodrębnia trzy typy pytań ${ }^{7}$ : 1 . deskryptywne - wymagające opisania czegoś, nadawca kieruje uwagę odbiorcy na właściwości zjawisk będących przedmiotem poznania; 2. o wyjaśnienie - uczące operowania posiadaną wiedzą; 3. wartościujące. Z kolei Bogusław Skowronek (1999), uwzględniając sytuację lekcyjną, wyróżnia cztery rodzaje pytań: 1. upewniająco-instrumentalne — pełniące funkcje pomocnicze podczas lekcji; 2. merytoryczne — związane treściowo z tematem omawianym podczas lekcji; 3. o funkcji metadydaktycznej, których głównym celem jest uzyskanie informacji dotyczących samego przebiegu lekcji oraz 4. niezwiązane z sytuacją lekcyjną.

Autor kolejnej klasyfikacji, Robert Fisher, dzieli pytania ze względu na podstawowe funkcje, jakie pełnią w procesie nauczania-uczenia się, i na tej podstawie wyróżnia pytania pobudzające dzieci do samodzielnego myślenia oraz pytania sprawdzające ich stan wiedzy (zob. rysunek 1).

$\mathrm{W}$ procesie kształcenia powinny być stosowane pytania należące do obu kategorii. Pierwszy typ pytań rozwija myślenie wyżej zorganizowane. Do tej grupy należą pytania aktywizujące ucznia, pobudzające zainteresowanie podejmowanym zagadnieniem. Pytania te umożliwiają formułowanie własnych rozważań, wniosków opartych na wcześniejszych analizach. Często pobudzają do dyskusji, która umożliwia rozwiązanie postawionego w pytaniu problemu. Druga grupa

3 Stosowanie w pytaniach rozstrzygnięciach partykuły czy nie jest nieodzowne, ponieważ funkcję pytajną można zasygnalizować wyraźnie wznoszącą się intonacją.

4 Jak zauważa Wojciech Kojs, choć struktura pytania dopetnienia ma charakter funkcji zdaniowej, to jednak z mniejszą możliwością podstawień, ponieważ przy podstawieniach w funkcji zdaniowej nie wolno mieszać kategorii semantycznych (wymienia się trzy takie kategorie), a zaimków i przysłówków pytajnych jest znacznie więcej (Kojs 1994: 34).

5 Zob. m.in. Biłos 1992; Kojs 1975, 1994; Nocoń 1994; Kawka 1999; Skowronek 1999.

${ }^{6}$ Autor opracowania zastrzegł przy tym, iż nie jest to klasyfikacja zamknięta.

7 Klasyfikacja Nocoń obejmuje pytania dotyczące systemu języka. Moim zdaniem może dotyczyć również innych zjawisk, nie tylko językowych. 


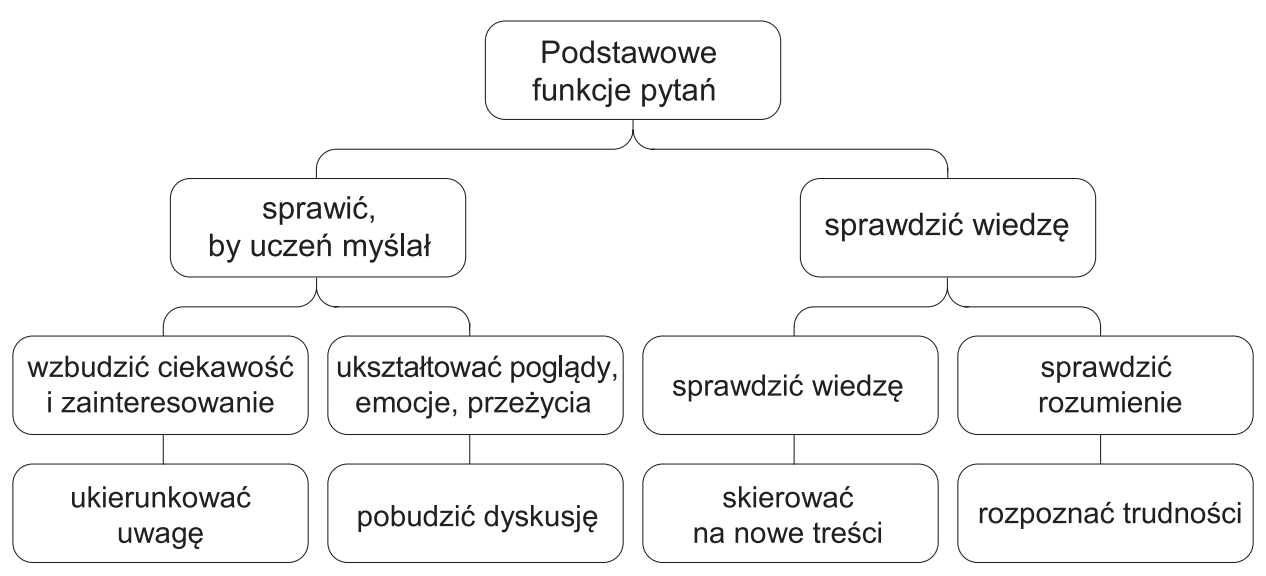

Rysunek 1. Dwie podstawowe funkcje pytań w procesie nauczania uczenia się

Źródło: Fisher 1999: 29.

pytań rozwija myślenie niżej zorganizowane i jest ściśle związana z rolą nauczyciela. Służy sprawdzaniu poziomu rozumienia przez dziecko treści i rozpoznaniu ewentualnych trudności. Dzięki pytaniom tego typu można poprawiać ewentualne błędy popełniane przez ucznia i umiejętnie naprowadzić go na poszukiwanie nowych rozwiązań.

Na potrzeby tego artykułu przyjęłam propozycję Elizabeth Perrott, która, uwzględniając „,taksonomię celów edukacyjnych” Benjamina Blooma, zaproponowała podział pytań ze względu na typ procesu myślowego uruchomianego podczas odpowiedzi. Perrott podzieliła pytania dydaktyczne na dwie zasadnicze grupy: pytania niższego rzędu oraz pytania wyższego rzędu. Pierwsza grupa obejmuje pytania typu: przypominanie, zrozumienie i zastosowanie, uruchamiające myślenie reproduktywne, w drugiej natomiast mieszczą się pytania analityczne, syntetyczne oraz ewaluacyjne, wymagające myślenia, które utożsamia się z rozwiązywaniem problemów (zob. tabela 1).

Klasyfikacja Perrott posłużyła mi do analizy pytań zadawanych uczniom w czasie rozmowy ${ }^{8}$ maturalnej. Materiał badawczy stanowi trzydzieści rozmów ${ }^{9}$ zarejestrowanych na dyktafonie podczas ustnego egzaminu maturalnego z języka polskiego ${ }^{10}$. Średnio w trakcie egzaminu zespół przedmiotowy zadawał pięć pytań (od dwóch do jedenastu w czasie rozmowy).

8 Egzamin trwa około 30 minut i składa się z trzech części: przygotowania (15 minut), wypowiedzi monologowej dotyczącej wylosowanego polecenia (trwającej około 10 minut) oraz związanej z tą wypowiedzią rozmowy maturzysty z komisją egzaminacyjną (na którą przeznaczonych jest około 5 minut).

9 Analizowałam materiał z trzech rozmów jednego zespołu przedmiotowego (składającego się z dwóch nauczycielek). W sumie badanie objęło 20 różnych nauczycieli.

${ }^{10}$ Próbny ustny egzamin z języka polskiego został przeprowadzony w kilkudziesięciu losowo wybranych szkołach ponadgimnazjalnych, zarówno liceach ogólnokształcących, jak i technikach. Nagrania udostępnił mi Instytut Badań Edukacyjnych. 
Tabela 1. Kategorie pytań ze względu na poziom myślenia, jakiego wymagają

\begin{tabular}{|c|c|c|c|c|c|}
\hline $\begin{array}{l}\text { Kat. } \\
\text { celów } \\
\text { kształ. }\end{array}$ & $\begin{array}{l}\text { Poziom } \\
\text { taksonom. } \\
\text { osiągnięć }\end{array}$ & $\begin{array}{c}\text { Kategoria } \\
\text { pytania }\end{array}$ & Kategoria czynności & $\begin{array}{l}\text { Przykładowe pyta- } \\
\text { nia i operatory }\end{array}$ & $\begin{array}{l}\text { Poziom } \\
\text { pytań }\end{array}$ \\
\hline \multirow{3}{*}{ 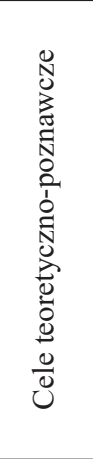 } & $\begin{array}{c}(\mathrm{W}) \\
\text { znajomość }\end{array}$ & $\begin{array}{l}\text { przypo- } \\
\text { minanie }\end{array}$ & $\begin{array}{l}\text { 1. odtworzenie faktów, za- } \\
\text { obserwowanych zjawisk czy } \\
\text { definicji }\end{array}$ & $\begin{array}{l}\text { kto?, co?, gdzie?, } \\
\text { kiedy?, } \\
\text { podaj definicję, } \\
\text { wymień cechy }\end{array}$ & niższy \\
\hline & \multirow{2}{*}{$\begin{array}{l}(\mathrm{W}) \\
\text { rozumie- } \\
\text { nie }\end{array}$} & $\begin{array}{l}\text { zrozumie- } \\
\text { nie }\end{array}$ & $\begin{array}{l}\text { 2. podanie opisu, określenie } \\
\text { głównych myśli, porównanie } \\
\text { i skontrastowanie }\end{array}$ & $\begin{array}{l}\text { opisz, określ głów- } \\
\text { ną myśl, porównaj, } \\
\text { skontrastuj }\end{array}$ & niższy \\
\hline & & $\begin{array}{l}\text { zastoso- } \\
\text { wanie }\end{array}$ & $\begin{array}{l}\text { 3. zastosowanie zasad i tech- } \\
\text { nik postępowania do rozwią- } \\
\text { zania problemu mającego } \\
\text { jedną właściwą odpowiedź }\end{array}$ & $\begin{array}{l}\text { zastosuj, sklasyfi- } \\
\text { kuj, wybierz, użyj }\end{array}$ & niższy \\
\hline \multirow{2}{*}{ 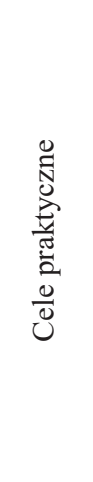 } & \multirow[t]{2}{*}{$\begin{array}{l}(\mathrm{U}) \\
\text { umiejęt- } \\
\text { ność }\end{array}$} & analiza & $\begin{array}{l}\text { 4. określenie motywów lub } \\
\text { przyczyn, wnioskowanie, } \\
\text { poszukiwanie dowodów/ar- } \\
\text { gumentów podtrzymujących } \\
\text { uogólnienia }\end{array}$ & $\begin{array}{l}\text { dlaczego?, znajdź } \\
\text { przyczynę, uzasad- } \\
\text { nij, podaj przykła- } \\
\text { dy świadczące o..., } \\
\text { sformułuj kon- } \\
\text { kluzję, wyciągnij } \\
\text { wnioski }\end{array}$ & wyższy \\
\hline & & synteza & $\begin{array}{l}\text { 5. rozwiązywanie proble- } \\
\text { mów, dokonywanie prze- } \\
\text { widywania, prezentowanie } \\
\text { problemu we własny orygi- } \\
\text { nalny sposób }\end{array}$ & $\begin{array}{l}\text { rozwiąż problem, } \\
\text { zaproponuj, zapla- } \\
\text { nuj, napisz, rozwiń }\end{array}$ & wyższy \\
\hline 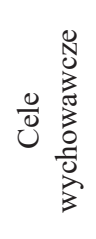 & $\begin{array}{c}(\mathrm{P}) \\
\text { postawa }\end{array}$ & ewaluacja & $\begin{array}{l}\text { 6. wyrażanie opinii na dany } \\
\text { temat, ocenianie sensow- } \\
\text { ności pomysłów, osądzanie } \\
\text { wartości rozwiązania proble- } \\
\text { mu, ocenianie wartości dzie- } \\
\text { ła literackiego czy sztuki }\end{array}$ & $\begin{array}{l}\text { osądź, oceń, wyraź } \\
\text { swoją opinię, osza- } \\
\text { cuj, zdecyduj }\end{array}$ & wyższy \\
\hline
\end{tabular}

Źródło: opracowanie własne na podstawie Perrott 1995: 51.

\section{Rozmowa maturalna}

Jak wiadomo, w 2015 roku w liceach (w 2016 roku w technikach) ustny egzamin maturalny się zmienił. Wcześniej przygotowywaną przez ucznia prezentację zastąpiono powstającą $\mathrm{w}$ trakcie egzaminu dłuższą wypowiedzią monologową oraz rozmową. $\mathrm{Z}$ informacji $\mathrm{w}$ informatorze wynika, że rozmowa maturalna nie może polegać jedynie na „odpytaniu” ucznia. Powinna dotyczyć wyłącznie wygłoszonej przez zdającego wypowiedzi monologowej, a członkowie zespołu egzaminacyjnego nie mogą odwoływać się do faktów lub lektur nieprzywołanych w tej 
wypowiedzi. W trakcie rozmowy członkowie zespołu mogą prosić o dodatkowe wyjaśnienia, zachęcać do pogłębienia wybranych aspektów wypowiedzi itp., pytania nie mogą jednak dotyczyć faktograficznych detali dotyczących lektury czy omówionych tekstów kultury, niepowiązanych z problemem określonym w temacie zdającego (https://cke.gov.pl/images/_EGZAMIN_MATURALNY_OD_2015/ Informatory/2015/Jezyk-polski.pdf [dostęp: wrzesień 2018]).

Oznacza to, że funkcja dydaktyczna pytań rozmowy maturalnej polega nie tylko na sprawdzeniu wiedzy, na żądaniu podania informacji, którą egzaminator zna, chcąc sprawdzić jej wiarygodność i prawidłowość, a niekiedy skonfrontować swoją wiedzę z wiedzą ucznia (Kawka 1999: 58), lecz również na pomocy pytającemu w rozstrzyganiu wątpliwości czy w wypełnianiu oczekiwanej odpowiedzi informacją jemu nieznaną. Spełnienie tych warunków powoduje, że rozmowa maturalna zbliża się swoim charakterem do rozmowy naturalnej, której podstawową funkcją jest porozumienie dokonujące się w akcie współpracy: „Jest to zwykle (rozmowa), przynajmniej w pewnym stopniu akt współpracy. Każdy uczestnik wiąże z nim cel [...] w pewnej mierze wspólny, a co najmniej akceptuje jakiś jego wspólny kierunek" (Grice 1980: 96). Oczywiście, mowa tu o zaproponowanej przez Paula Grice’a zasadzie kooperacji: „wnoś swój wkład do konwersacji tak, jak tego w danym stadium wymaga cel czy przyjęty kierunek wymiany słów, w której bierzesz udział" (rozwiniętej czterema kategoriami: ilości, jakości, stosunku i sposobu) (Grice 1980: 96-97). Rozmowę maturalną można by zatem traktować jako komunikację wolną od „schematu myślenia opartego na walce, czyli współbycie, społeczne współdziałanie, otwarcie na Innego [...], oraz jako proces rozumienia, ustalania wspólnego języka, umożliwiającego porozumienie z Innym, tym również z tekstem kultury" (Myrdzik 2000: 98).

Zdaniem Barbary Myrdzik (2000: 100-101) prowadzenie dobrej rozmowy wymaga od partnerów, aby:

— „nie rozmijali się w niej”, mieli zarysowany kierunek i cel;

— upewniali się, czy partner rozmowy nadąża;

— podporządkowali się sprawie, na której skupiają uwagę;

— nie dążyli do przekonania innego w dyskusji za wszelką cenę, ale uwzględnili rzeczową wagę odmiennego poglądu;

— umieli stworzyć atmosferę sprzyjającą wymianie myśli;

— potrafili uważnie słuchać, byli cierpliwi;

- stawiali trafne pytania i formułowali celne odpowiedzi.

Dlatego nie tyle brak odpowiedzi, ile nieumiejętność stawiania pytań zatrzymuje rozmowę powoduje, że przestaje się ona rozwijać. Pożądane byłyby więc przede wszystkim pytania analityczne, syntetyzujące i ewaluacyjne, uruchamiające procesy myślowe wyższego rzędu o charakterze twórczym, refleksyjnym oraz oceniającym, zawierające nośniki pobudzające rozmowę. 


\section{Typy pytań stawianych podczas rozmowy maturalnej}

Jakie zatem pytania stawiają nauczyciele podczas rozmowy maturalnej? Wykres 1 przedstawia stosunek pytań niższego i wyższego rzędu. Wynika z niego, że ponad $70 \%$ pytań w badanym materiale to pytania uruchamiające myślenie niższego rzędu (zob. wykres 1).

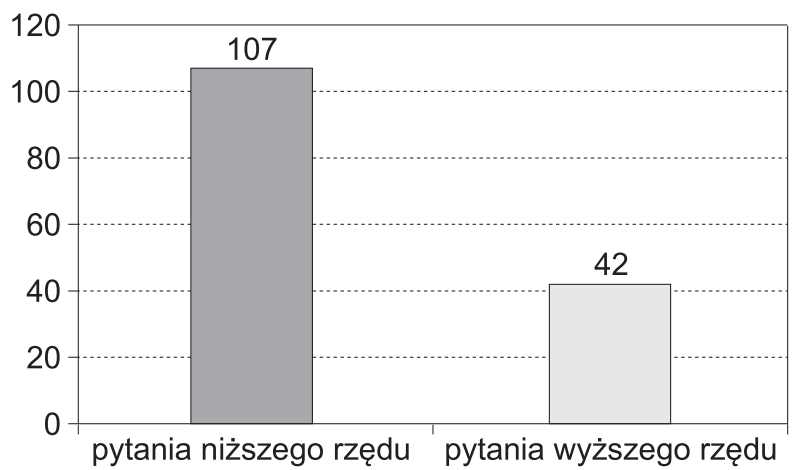

Wykres 1 . Stosunek liczby pytań wyższego rzędu do liczby pytań niższego rzędu

Źródło: opracowanie własne.

Szczegółowy wynik występowania poszczególnych kategorii pytań w analizowanych rozmowach ilustruje wykres 2 .

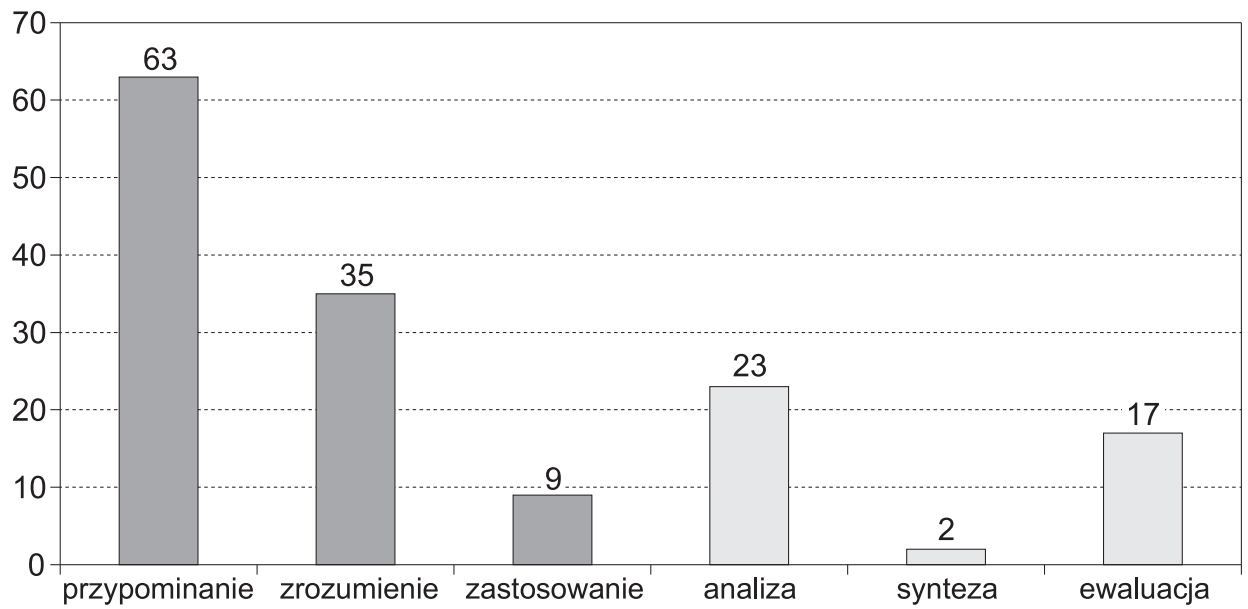

Wykres 2. Kategoria i liczba pytań zadawanych przez nauczycieli podczas rozmowy

Źródło: opracowanie własne. 
Wśród pytań niższego rzędu przeważały pytania sprawdzające wiedzę ucznia (pytania typu przypominanie stanowią ponad $42 \%$ wszystkich pytań), na przykład:

1) Czy wiesz, co to za gatunek sielanka, jakie są wyznaczniki tego gatunku?

2) Przywołałeś biblijną Przypowieść o siewcy. Jakie są cechy tego gatunku?

3) Z jakiej odmiany językowej pochodzą te wyrazy?

4) Powiedziałeś, że Bóg występuje jako element, bohater w przysłowiach, a przysłowia to przykład mądrości ludowej, ale przykład dałeś o jednym ze świętych. Jakie znasz przysłowia, w których Bóg, samo słowo Bóg występuje?

5) Mówiłeś, że w Lalce przywoływałeś przedstawicieli różnych klas, bądź uprzejmy uporządkować, wymieniając jeszcze raz, jakie warstwy społeczne opisuje Prus?

Odpowiedzi na tego typu pytania polegają jedynie na przypomnieniu przez ucznia specyficznych faktów, wiadomości, które uprzednio usłyszał na lekcji lub przeczytał w innych źródłach, na przykład w podręczniku. Nauczyciel z łatwością jest w stanie ocenić poprawność odpowiedzi: czy pytany wie, co to jest sielanka, czy zna wyznaczniki gatunkowe przypowieści, czy zna treść lektury itp. Niewątpliwie sama formuła egzaminu powoduje, że nauczyciele często sprawdzają wiedzę. Jednak nie można przemilczeć tego, że z tą kategorią wiążą się pewne niebezpieczeństwa - jednym z nich jest tendencja do nadużywania przez nauczycieli tego typu pytań ${ }^{11}$, przez co ocenie podlega ,tylko powierzchowne rozumienie zjawisk" (Perrott 1995: 45). Poza tym pytania wymagające od ucznia przypomnienia sobie czegoś często skłaniają do zwięzłych odpowiedzi, przez co rozmowa traci swój naturalny rytm i przestaje się rozwijać, ma kształt typowej rozmowy egzaminacyjnej: „akcja - reakcja”, a uczeń ma nikły wpływ na jej przebieg, co ilustruje poniższy dialog:

- (N1) Mówiłeś o idylli i sielance, idylla to jest właśnie sielanka, idylla to wyraz obcego pochodzenia, a sielanka rodzimy. Czy mógłbyś wymienić jej cechy gatunkowe?

- (U) Sielanka \| to pewnie jakieś pozytywne zakończenie \| jednowątkowość akcji może..., chociaż niekoniecznie, nie wiem.

- (N1) Powiedziałeś i słusznie, że Pan Tadeusz ma cechy baśni i wskazałeś elementy baśniowego, typowego dla tego gatunku zakończenia, o tym, że autor, przepraszam, narrator utożsamia się, yyy tam był, widział i księgę tak zapisał. Ale oprócz tego, tej formalnej, tego formalnego zakończenia, jest jeszcze dobre zakończenie, to znaczy, że wszystko dobrze się kończy. Czy mógłbyś rozwinąć, proszę podaj przykłady i potwierdzić znajomością tekstu, że akcja się dobrze kończy, że wątki są zakończone?

- (U) Tak więc wątek Tadeusza, który na koniec epopei bierze ślub z Zosią, oczyszczenie z zarzutu księdza Robaka, czyli Jacka Soplicy, z oskarżenia o umyślne zabójstwo przodka Horeszków, który, jak się okazało, przypadkiem chciał strzelić do Moskala, a przypadkiem ta kula trafiła przodka Horeszków i właśnie od tego zaczął się konflikt między rodami, i to chyba wszystko.

- (N2) Użyłeś sformułowania, że Pan Tadeusz zawiera elementy epiki heroikomicznej i zacząłeś pozytywnie analizować pojęcie, że pokazuje bohaterów herosów, ale w jakich sytuacjach, czyli czy mógłbyś przejść do drugiej części tego określenia — heroikomiczny — i wskazać w treści Pana Tadeusza takie właśnie sytuacje?

11 Badania sprawdzające częstość stosowania poszczególnych kategorii pytań podczas egzaminu należałoby przeprowadzić na szerszą skalę, ale już moje skromne obserwacje potwierdzają tę hipotezę. 
- (U) Heroikomiczny yyy czyli bohaterowie w sytuacjach komicznych. Tylko tak ciężko będzie tak przywołać coś. || Nie przypomnę sobie.

Powyższy dialog zawiera dość rozbudowane pytania z kategorii „wiedza” i raczej krótkie odpowiedzi. W dwóch z nich uczeń przyznaje, że nie potrafi odtworzyć wiedzy, o którą jest pytany („nie wiem”, „nie przypomnę sobie”). Korzystając z propozycji Urszuli Żydek-Bednarczuk (1994), która za podstawową jednostkę rozczłonkowania rozmowy uznała „krok”, cytowaną rozmowę można przedstawić następująco:

$\left(\mathrm{N}_{1}\right)$ inicjacja

$$
\text { (U) reakcja }
$$

$\left(N_{1}\right)$ inicjacja 4

(U) reakcja

$\left(\mathrm{N}_{2}\right)$ inicjacja

(U) reakcja

Rysunek 2. Kroki rozmowy egzaminacyjnej.

Źródło: opracowanie na podstawie Żydek-Bednarczuk 1994.

Nauczyciel „trzykrotnie” inicjuje rozmowę, zadając trzy różne pytania bez odnoszenia się do wcześniejszych odpowiedzi ucznia.

Kolejną co do liczebności grupę pytań stanowią pytania sprawdzające rozumienie $(23,5 \%)$, na przykład:

6) Uporząakuj, proszę, informacje. Kto jest autorem recenzji i o czyim filmie autor mówi w recenzji?

7) Powiedziałeś, że recenzent ma krytyczny stosunek do tego filmu. Co krytykuje?

8) [...] Użyłeś określenia, że to jest nadrealistyczna koncepcja. Wyjaśnij, jak rozumiesz to pojęcie?

9) [...] W tej recenzji pada takie sformułowanie „wierne odstępstwo" [...] jak pan rozumie to sformułowanie?

Celem tej kategorii pytań jest pomoc uczniowi w operowaniu posiadaną wiedzą, uporządkowaniu przedstawianych faktów, które pojawiły się w jego wypowiedzi (przykład 6). W pytaniach tego typu nauczyciel często prosi o dodatkowe wyjaśnienia (przykład 8), czasem o uzupełnienie wypowiedzi o brakujące elementy (przykład 7). Niewątpliwie pytania te mają charakter „współpracujący” — dowodzą uważnego słuchania nauczyciela, skupienia uwagi na wspólnym celu dialogu, a uwzględnienie opinii drugiej osoby w sformułowaniach: „Jak (ty) rozumiesz?”; „Jak pan rozumie” może dowodzić, że pytający są skłonni przyjąć inne niż zakładają ujęcia zjawisk, faktów, pojęć.

Ostatnia, najmniej liczna grupa pytań niższego rzędu to pytania typu zastosowanie (6\%). Zadaniem tej kategorii pytań jest zachęcenie uczniów, by użyli zdobyte wcześniej już informacje do rozwiązania problemu. Pytania: 
10) Czy umiałabyś dokonać analizy składniowej głównego hasła reklamy?

11) [...] Czy w baśni Andersena odnajdujesz jakąś prawdę na temat mechanizmów manipulacji?

12) Przywołałeś Kwiatki św. Franciszka [...]. Czy rzeczywiście jest to tekst będący wskazówką dla współczesnego człowieka [...]?

13) W swojej wypowiedzi użyłaś sformułowania, że to tekst-oskarżenie. Dlaczego?

skłaniają ucznia do „przyłożenia wzoru, zasady czy procesu” do rozwiązywanego problemu, co jest niezbędne podczas formułowania właściwej odpowiedzi. Proces poznawczy przebiega tu od teorii (,wiedzy o") do zastosowania jej na konkretnym materiale. W cytowanych przykładach uczniowie, by poprawnie odpowiedzieć na zadane pytania, musieli wykazać się wiedzą o elementach struktury języka i umiejętnością zastosowania jej do analizy składniowej hasła „Twoja laska po wypadku” (przykład 10) ${ }^{12}$, orientacją dotyczącą technik manipulacyjnych, by móc je wskazać w baśni Nowe szaty cesarza (przykład 11), znajomością literatury hagiograficznej - wzorca osobowego świętego - by rozwiązać problem postawiony w pytaniu (przykład 12) czy wreszcie wiedzą o wyznacznikach gatunkowych oskarżenia by wskazać je w analizowanym tekście (przykład 13).

Za niepokojące można uznać to, że blisko w połowie z trzydziestu analizowanych rozmów pojawiały się pytania wyłącznie niższego rzędu. Przykładem tego zjawiska jest poniższy dialog:

— (N1) Słuchając twojej wypowiedzi || yyy tutaj nasunęło mi się takie pytanie: Kim jest Marek Kondrat? || Czy ty wiesz, o jaką postać chodzi? Kto to jest?

- (U) Marek Kondrat to artysta, który yyy żył już po wojnie [...] yy wspomina powstanie warszawskie jako coś yy w czym tak naprawdę nie brał udziału [...].

- (N1) Mówisz: artysta, a mogłabyś skonkretyzować, jaki konkretnie artysta, czym się zajmuje?

- (U) Pisarz.

— (N1)|| yyy [z rezygnacją] Drugie moje pytanie brzmi tak: przed jakim dylematem moralnym stanęli poeci z pokolenia Krzysztofa Kamila Baczyńskiego i jak ten dylemat ocenia Kondrat w swojej wypowiedzi?

- (U) yyy Chodzi tu o dylemat: albo wybrać walkę za ojczyznę [...], straty moralne, straty też tak naprawdę rodziny, bo walka wiąże się również ze stratą domu, całego życia [...], albo wybrać beztroskie życie tak naprawdę wobec yy wobec wojny, nie brać w niej udziału i zostać jakoś z boku.

[brak komentarza, cisza trwająca $23 \mathrm{~s}$, przewracanie kartek]

- (N2) Kogo Marek Kondrat ma na myśli, mówiąc obraźliwy [Pomnik Małego Powstańca]?

- (U) Ma na myśli tych, te osoby, które brały udział w powstaniu yy wcześniej wspomina te osoby, które mają za duże płaszcze, za duże buty, co również ten pomnik świetnie podkreśla [...].

Podczas rozmowy uczeń ma udowodnić jedynie, że pamięta specyficzne fakty i wiadomości, które były poprzednio „,przerabiane” na lekcji albo są powszechnie znane. W cytowanym przykładzie pytany ma się wykazać znajomością posta-

12 Do zadania: „Jakie funkcje pełni podany tekst kultury? Wskaż i scharakteryzuj środki językowe oraz niejęzykowe, które zostały w nim wykorzystane do realizacji tych funkcji” dołączony był materiał w postaci plakatu wykorzystanego w kampanii społecznej „Młodzi kierowcy”, http:// www.kampaniespoleczne.pl (dostęp: 10.08.2016). 
ci: „Kim jest Marek Kondrat?”13, zdarzeń historycznych, kontekstów literackich: „Przed jakim dylematem moralnym stanęli poeci z pokolenia Krzysztofa Kamila Baczyńskiego?" oraz umiejętnością czytania ze zrozumieniem na poziomie dosłownym, ponieważ odpowiedzi na pytania „Jak ten dylemat ocenia Kondrat w swojej wypowiedzi?”, „Kogo Marek Kondrat ma na myśli, mówiąc obraźliwy?” znajdzie wprost w tekście. Cytowany przykład to rozmowa, w czasie której uczeń, odtwarzając gotową wiedzę, może „wyłączyć myślenie”.

Pozostałe dialogi zawierały pytania zarówno niższego, jak i wyższego rzędu. Dwadzieścia trzy pytania (15,5\%) dotyczyły analizy. Przykładowo:

14) Powiedziałeś, że w dzisiejszych czasach kłamstwo jest na porządku dziennym. Jakie są tego przyczyny?

15) Jaki związek mają słowa klucze ze światem wartości?

16) Używasz sformułowania, że zauważasz we współczesności przeszkody do osiągnięcia drugiej przestrzeni. Co dla Ciebie jest drugą przestrzenią i jakie przeszkody współczesny człowiek zauważa?

17) Dlaczego twoim zdaniem Miłosz określa się mianem poety moralisty?

Pytania analityczne wymagają od ucznia myślenia krytycznego. Maturzysta nie może odpowiedzieć na nie, powtarzając wyuczone fakty, wiadomości, wymagają one bowiem analizowania informacji w celu: rozpoznania motywów i przyczyn danego zjawiska (przykład 14); rozważenia i przeanalizowania dostępnych informacji mających pomóc we wskazaniu konkluzji (przykłady 15 i 16); znalezienia dowodów (przykład 17). Odpowiadając na tego typu pytania, uczeń uruchamia myślenie dywergencyjne umożliwiające mu rozwiązanie postawionego w pytaniu problemu o charakterze otwartym, niemającym jednego słusznego rozwiązania. Ten rodzaj pytań jest szczególnie cenny, ponieważ odpowiedzi na nie dokumentują, czy uczeń potrafi myśleć logicznie, czy dostrzega związki między poszczególnymi elementami struktury problemu, czy też wykrywa nowe związki. Uczniowskie odpowiedzi na pytania analityczne znacznie częściej skłaniają nauczyciela do wejścia w rzeczywisty dialog z uczniem, w którym podtrzymywana i rozwijana przez obie strony jest jedna główna linia tematyczna (w przeciwieństwie do typowej rozmowy egzaminacyjnej, zob. rysunek 2).

Zaskakujące jest to, że w badanym materiale tylko dwa pytania miały charakter syntezy:

18) Zapytałam ciebie o słowa klucze, wartości, jakie funkcjonują w ogóle w naszej kulturze. Gdyby w obecnym świecie młodych funkcjonowały wartości wymienione przez ciebie, jaki miałyby wpływ na ten świat? Czy zmieniłby się?

19) Jak podsumujesz wybór Adama Mickiewicza dotyczący tej wielogatunkowości Pana Tadeusza?

Pytania tego typu badają przede wszystkim, jak głęboko uczeń rozumie daną sprawę (Perrott 1995: 48), często wymagają od pytanego pewnego przewidywania

13 Można mieć wątpliwości, czy wiedza, kim jest Marek Kondrat, w jakiś szczególny sposób pomaga w ustosunkowaniu się do problemu. 
(przykład 18), rozwiązywania problemów, nierzadko dokonywania nietypowych, oryginalnych połączeń między zjawiskami, faktami (przykład 19), będących swoistą syntezą. Wydaje się, że zwłaszcza te pytania powinny być powszechnie stosowane przez nauczycieli nie tylko na lekcji, lecz także podczas egzaminu. Uczeń, aby odpowiedzieć na pytania o syntezę, nie tylko musi przypomnieć sobie pewne informacje (chociażby na temat synkretyzmu gatunkowego Pana Tadeusza — przykład 19), ale musi również wyjść poza nie, przetworzyć i spożytkować je w twórczy sposób.

Ostatnia już grupa pytań kierowanych do ucznia to pytania ewaluacyjne, będące prośbą o wyrażenie opinii na dany temat. W analizowanych rozmowach jest ich siedemnaście (11,5\%). Przykładowo:

20) A co najbardziej zrobiło na tobie wrażenie w tej reklamie i jest dla ciebie najbardziej przejmujące?

21) Jak oceniasz wykorzystanie dzieł sztuki wysokiej przez producentów, marketingowców, biznesmenów do tego, żeby zwiększyć właśnie sprzedaż produktów. Jak to oceniasz?

22) A dla ciebie, który z tych gatunków odgrywa najważniejszą rolę w Panu Tadeuszu?

23) [...] ale czy jeśli ma to docierać do młodych ludzi, to czy uważasz, że to jest efektywne [...] żeby zwrócić uwagę, żeby zmusić do refleksji, o której wcześniej mówiłaś?

Pytania ewaluacyjne są rzeczywistymi pytaniami, ponieważ spełniają najważniejszy warunek pragmatyczny dla funkcji pytania — posiadanie luki informacyjnej, którą pytający chce uzupełnić. Można je uznać za szczególnie cenne, ponieważ są otwarte i mogą wyrażać autentyczne zainteresowanie nauczycieli opinią czy oceną ucznia, która może dotyczyć sposobu proponowanego rozwiązania problemu, oceną wartości tekstów kultury, dzieł sztuki, dzieł literackich (przykłady 20, 21, 22 i 23). Zadawanie pytań tego typu zbliża rozmowę egzaminacyjną do autentycznego dialogu opartego na współdziałaniu. „Współdziałanie wymaga założenia, że temat lub rozstrzygany problem jest jakby białą kartą, którą się wspólnie zapisuje [...], jest przeciwstawianiem się modelowi autorytarnemu, w którym prawo do słuszności przysługuje wyłącznie nauczycielowi [...], nadzieją na sensowną współpracę" (Bortnowski 2011: 116 n.).

\section{Podsumowanie}

Wyrażam przekonanie, że proces egzaminowania, zwłaszcza podczas ustnej rozmowy maturalnej, powinien być bliski autentycznej rozmowie, którego podstawową kategorią jest dialog odrzucający wszelkie formy komunikacji oparte na strategii walki. Dialog, w którym nauczyciele egzaminatorzy zrezygnują z manipulacji własną wiedzą, dialog mający charakter „komunikacji sensów”, służący poszukiwaniu prawdy i otwarciu się na drugiego. Dialog, dzięki któremu uczeń nie będzie się czuł jedynie przepytywany. Dialog, w którym obie strony mają wpływ na jego przebieg, ponieważ zdarzenie interakcyjne jest czymś, ,co się wy- 
darza między ludźmi, a nie czymś, co jedna osoba czyni drugiej" (Stewart 2000: 45). Znaczyłoby to, że rola ucznia polegałaby nie tylko na odtwarzaniu gotowej wiedzy (a zwykle tego oczekuje się od ucznia podczas egzaminu), lecz także na byciu „oczekującym mówcą”, „słuchaczem dialogicznym”. Jedną z dróg, by egzamin ustny stał się bliski rozmowie naturalnej, jest stawianie pytań otwartych, uruchamiających procesy myślenia wyższego rzędu (pytania analityczne, o syntezę i ewaluacyjne stanowiły niecałe $30 \%$ badanego materiału). Tego typu pytania dają uczniowi zarówno możliwość wykazania się wiedzą, jak i — co ważniejsze — prawo do wyrażania własnych refleksji, poglądów, opinii dotyczących podejmowanych tematów.

\section{Bibliografia}

Awdiejew A., 1987, Pragmatyczne podstawy interpretacji wypowiedzeń, Kraków.

Biłos E., 1992, Wypowiedzenia pytajne w nauczaniu języka polskiego, Częstochowa.

Bortnowski S., 2011, Przewodnik po sztuce uczenia literatury, Warszawa.

Fisher R., 1999, Uczymy jak się uczyć, przeł. K. Kruszewski, Warszawa.

Grice H.P., 1975/1980, Logika a konwersacja, przeł. B. Stanosz, [w:] Język w świetle nauki, red.

B. Stanosz, Warszawa, s. 91-114.

Kawka M., 1999, Dyskurs szkolny. Zagadnienia języka, Kraków.

Kojs W., 1975, Uwarunkowania dydaktycznych funkcji podręcznika, Warszawa.

Kojs W., 1994, Pytania i polecenia w ksztatceniu systematycznym. Analiza operatorów, Katowice. Lyons J., 1989, Semantyka 2, przeł. A. Weinsberg, Warszawa.

Myrdzik B., 2000, Czy rozmowa jest metodą?, [w:] Nowoczesność i tradycja w ksztatceniu literackim. Podręcznik do ćwiczeń z metodyki języka polskiego, Lublin, s. 95-103.

Nocoń J., 1994, Polecenia i pytania w podręcznikach do nauki o języku, Opole.

Nocoń J., 2011, Stylistyczne aspekty dyskursu edukacyjnego, [w:] Odmiany stylowe polszczyznydawniej i dziś, red. U. Sokólska, Białystok, s. 187-200.

Perrott E., 1995, Efektywne nauczanie. Praktyczny przewodnik doskonalenia nauczania, przeł. A. Janowski, Warszawa.

Searle J., 1987, Czynności mowy, przeł. B. Chwedeńczuk, Warszawa.

Skowronek B., 1999, O dialogu na lekcjach w szkole średniej. Analiza pragmatyczno-językowa, Kraków.

Stewart J., 2000, Wprowadzenie do komunikacji interpersonalnej, przeł. J. Suchecki, [w:] Mosty zamiast murów. Podręcznik komunikacji interpersonalnej, red. J. Stewart, Warszawa.

Świdziński M., 1973, Analiza semiotyczna wypowiedzi pytajnych we współczesnym języku polskim, „Studia Semiotyczne” 4, s. 221-250.

Wierzbicka A., 1983, Genry mowy, [w:] Tekst i zdanie. Zbiór studiów, red. T. Dobrzyńska, Wroclaw, s. 125-137.

Żydek-Bednarczuk U., 1994, Struktura tekstu rozmowy potocznej, Katowice. 